\title{
Energy Effective Membrane-less Technology for High Pressure Hydrogen Electro-chemical Generation
}

Victor Solovey, Mykola Zipunnikov*, Andrii Shevchenko, Irina Vorobjova, Anatolii Kotenko Hydrogen Energetics Department, A.M. Pidhorny Institute of Mechanical Engineering Problems of NASU, 2/10, Pozharsky str., 61046, Kharkiv, Ukraine

*corresponding author: zipunnikov_n@ukr.net

Keywords: hydrogen, oxygen, active electrode, electrolyzer.

Water electrolysis process for hydrogen generation is widely used in various branches of industry. But it has disadvantages like important energy consumption and utilization of separate membranes, which limit the generated gases pressure.

This article describes the hydrogen and oxygen generation technology excluding the separating ion-exchange membranes and providing high gases pressure due to applying the variable valence metal chemically active electrodes as well as due to separating in time and space the electrolytic processes of water decomposition for gases liberation.

The electrolyzer based on this technology surpasses all of the known analogues by the level of technical decisions, simplicity of mounting and servicing, reliability and safety.

\section{Introduction}

Water electrolysis process for hydrogen generation is widely used in various fields of modern engineering by its ecological cleanness and simplicity of the technological scheme. Moreover, water supply is unlimited as the raw material for the electrolytic decomposition technologies.

The main disadvantages of the electrolysis process are big energy consumption and necessity to use of the separate membranes that limit the generated gases pressure. It is required to use the compressors for gas storage. Therefore, developing of hydrogen generation electrochemical technology providing minimal energy consumption is a perspective and importance way for hydrogen power engineering.

The decreased power consumption of the well-known electrolyzers is provided due to increasing the working temperature and applying the platinum and rare-earth group metals for electrodes production as well as due to applying the ion-exchange membranes that are expensive and complex for manufacturing.

All of the above mentioned reasons result in increasing cost of hydrogen generation systems and higher service requirements, as well as in decrease of systems reliability, in shortening of their resource and, the main thing, in limiting of upper pressure level of the generated gases. 
Therefore, the great potential for the electrolysis power engineering may be in creation of membrane-less high pressure electrochemical hydrogen $\left(\mathrm{H}_{2}\right)$ and oxygen $\left(\mathrm{O}_{2}\right)$ generation technology that provides the specific energy consumption not more than $3.85-4.0 \mathrm{~kW} / \mathrm{h}$ $[1,2]$.

The electrolyzer inmplementing such technology involves the electrolysis unit, gas-fluid flows separation system and the electronic unit intended to manage and control the electrolysis unit operation modes. The electrolysis unit is adapted to consume the "non-conditional" electrical power generated from the renewable power sources (wind, sun etc.) for producing hydrogen, an ecologically clean energy carrier, and oxygen gas.

\section{Purposes and research tasking}

The purposes of this study are to determine the mode parameters of the active electrode electrochemical reaction mass depending on the amount of the liberated $\mathrm{H}_{2}$ and $\mathrm{O}_{2}$. It results in finding the technological solution how to reduce the energy intensity of the highpressure $\mathrm{H}_{2}$ and $\mathrm{O}_{2}$ generation process and to completely abandon the compressing equipment from the system of gases generation and storage. These purposes can be achieved due to selecting the appropriate electrodes made from not expensive variable valence elements, as well as due to studying the membrane-less electrolysis cell operation when the gas pressure is increased up to $200 \mathrm{~atm}$.

\section{Experimental Part}

\section{Methods}

An experimental stand was developped to have the possibility for modeling the processes of $\mathrm{H}_{2}$ and $\mathrm{O}_{2}$ generation taking place in the electrochemical cells and to monitor these processes visually (Scheme 1). The method of experimental study of these processes is described in [3].

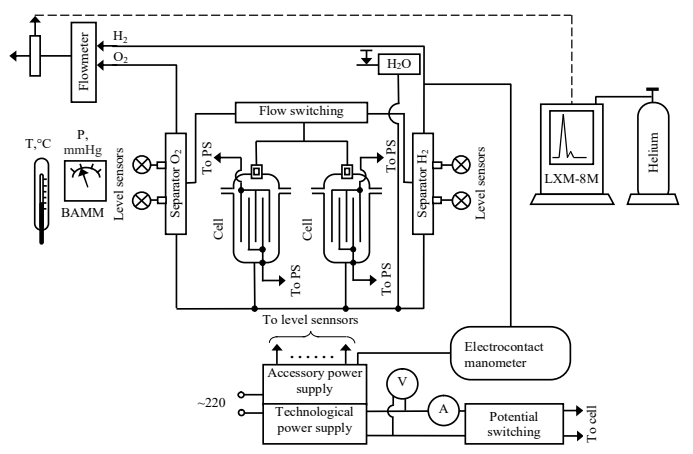

Scheme 1. The experimental stand with the electrochemical cells. PSU - power supply; ECM - electro contact manometer; LXM-8M chromatograph; BAMM - barometer;

This stand involves the system of $\mathrm{H}_{2}$ and $\mathrm{O}_{2}$ electrochemical generation, main pipes, separators, container with distilled water, power supply unit, control unit and a system for measuring the flow characteristics of generated gases. The system of $\mathrm{H}_{2}$ and $\mathrm{O}_{2}$ electrochemical generation involves two electrochemical cells.

The proposed technology for generating high-pressure $\mathrm{H}_{2}$ and $\mathrm{O}_{2}$ consists of two stages that involve periodically alternating oxidizing and reducing reactions with participation of the active mass of the gas-absorbing electrode. The waterdissociation reaction isolates hydrogen and oxygen simultaneously. The process of hydrogen 
generation begins with feeding the negative potential to the passive electrode. The hydrogen gas is inputted to the high pressure pipe. The gasabsorbing active electrode operates as an anode at this stage. The hydrogen is isolated at the passive electrode in the gaseous state, and the oxygen is chemically combined at the active electrode (i.e., it is accumulated as the chemical compound). Then, this active electrode is reconditioned into initial operational state during the following stage of electrolyzer operation. This allows automatic switching of electrodes to act as anode/cathode electrodes.

The separation devices were developed with the use of the method of the gas dynamic processes modeling [4].

\section{Results and discussion}

The main data were obtained experimentally under study of the electrochemical activity of the 08X18H10T-Fe electrode pair. The voltage change during the whole cycle of $\mathrm{H}_{2}$ and $\mathrm{O}_{2}$ generation under electrolysis process is shown on Figure 1.

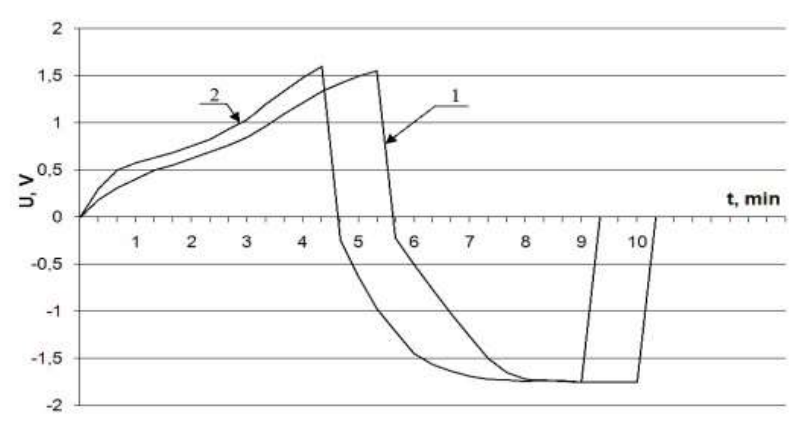

Figure 1. Variation of the voltage during the whole cycle of $\mathrm{H}_{2}$ and $\mathrm{O}_{2}$ generation under electrolysis process when the 08X18H10T-Fe electrode assembly is used. Current Density: 1-J $=0.015 \mathrm{~A} / \mathrm{cm}^{2} ; 2-\mathrm{J}=0.03 \mathrm{~A} / \mathrm{cm}^{2}$.

Analysis of the experimental results has provided the possibility for determining the rate of involving of the active iron electrode mass into the electrochemical reaction as a function of the specific density of the current fed to the electrolysis cell (Table 1).

Table 1. Results of electrochemical activity of the $08 \mathrm{X} 18 \mathrm{H} 10 \mathrm{~T}-\mathrm{Fe}$ electrode assembly.

\begin{tabular}{|c|c|c|c|c|c|c|}
\hline 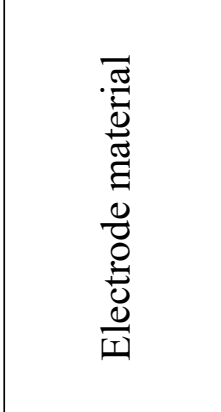 & 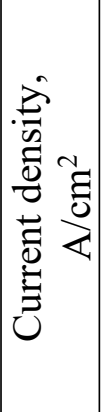 & 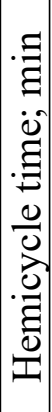 & 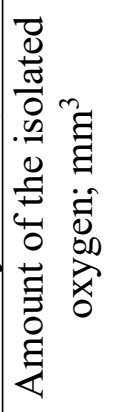 & 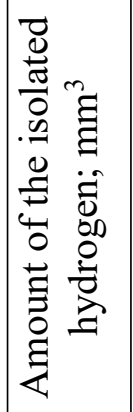 & 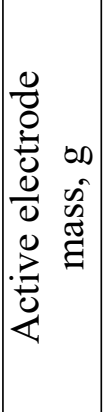 & 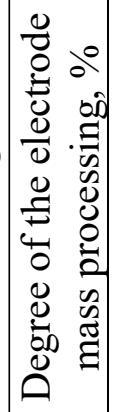 \\
\hline 8X18Н10Т- & 0,015 & 6 & $11 \cdot 10^{3}$ & $22 \cdot 10^{3}$ & & \\
\hline $\mathrm{Fe}$ & \begin{tabular}{|l|}
0,03 \\
\end{tabular} & 5 & $14 \cdot 10^{3}$ & $28 \cdot 10^{3}$ & & \\
\hline
\end{tabular}

The increase of voltage is accompanied by polarization taking place under electrode active mass oxidation caused by the slowing down the $\mathrm{OH}$ ions diffusion. For this, the diffusion rate decreases as the thickness of the reacted iron layer increases according to the following reactions:

$$
\mathrm{Fe}+2 \mathrm{OH}^{-}<=>\mathrm{Fe}(\mathrm{OH})_{2}+2 \mathrm{e}^{-},
$$

And under big depth of the active electrode reacting mass:

$$
\mathrm{Fe}(\mathrm{OH})_{2}+\mathrm{OH}^{-}<=>\mathrm{Fe}(\mathrm{OH})_{3}+\mathrm{e}^{-} .
$$

The gently sloping section of the first region on Figure 1 represents the voltage range of $0.28-0.54 \mathrm{~V}$ (reaction 1); the second flat region represents the voltage range from $0.54 \mathrm{~V}$ to $0.7 \mathrm{~V}$ (reaction 2). When oxidation and 
reduction cycles are carried out, the amount of iron that is used under the getter reaction is determined by the depth of its reduction in the surface layers of the active electrode. The difference between the amounts of reacted substance of the Table 2. The main parameters of compression of $\mathrm{H}_{2}$ and $\mathrm{O}_{2}$ in the high-pressure electrolyzer.

\begin{tabular}{|c|c|c|c|c|c|}
\hline 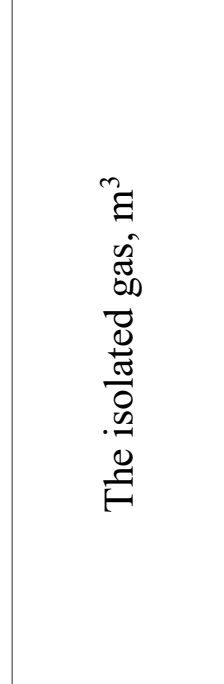 & 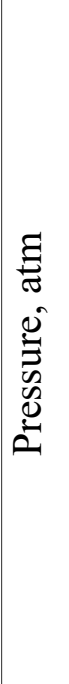 & 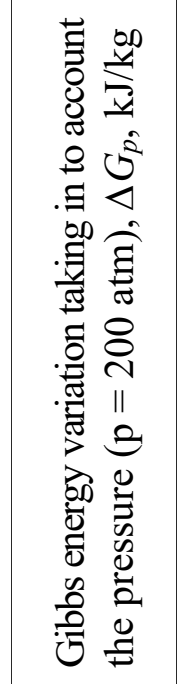 & 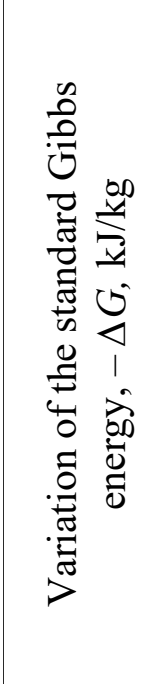 & 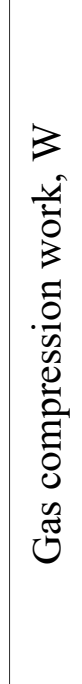 & \\
\hline $\begin{array}{c}\text { Hydrogen, } 1 \\
\mathrm{~m}^{3}\end{array}$ & & $2,296 \cdot 10^{8}$ & $2,366 \cdot 10^{8}$ & $\begin{array}{l}\widehat{N} \\
\infty \\
\infty\end{array}$ & \\
\hline $\begin{array}{c}\text { Oxygen, } 0,5 \\
\mathrm{~m}^{3}\end{array}$ & $\because$ & $1,42 \cdot 10^{7}$ & $1,46 \cdot 10^{7}$ & $\hat{n}$ & \\
\hline
\end{tabular}

porous iron electrode, when the current density is increased from 0.015 to $0.03 \mathrm{~A} / \mathrm{cm}^{2}$, is about $4 \%$. This indicates the growth of the reacting layer of the active electrode, $\left(\mathrm{Fe}(\mathrm{OH})_{2}, \mathrm{Fe}(\mathrm{OH})_{3}\right)$ depending on the increase of time of the oxidation and reduction hemicycles.

The developed electrolysis technology requires $\approx 3715 \mathrm{~W} \cdot \mathrm{h} / \mathrm{m}^{3}$ of energy to generate $1 \mathrm{~m}^{3}$ of $\mathrm{H}_{2}$ and $0.5 \mathrm{~m}^{3}$ of $\mathrm{O}_{2}$ without taking into account compression of these gases, and the compression of gases under the electrochemical process consumes $285 \mathrm{~W} \cdot \mathrm{h}$ due to increase of the generated gases pressure in the membrane-less electrolyzer: Table 2, Scheme 2.

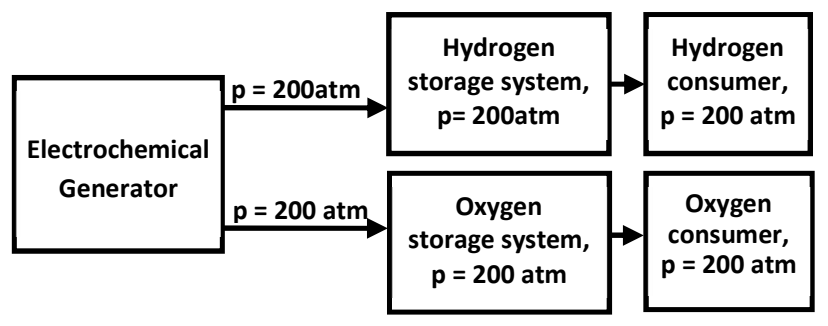

Scheme 2. The technological scheme of $\mathrm{H}_{2}$ and $\mathrm{O}_{2}$ production without compressors by the technology developed at the Institute of Mechanical Engineering Problems of NASU, Ukraine.

In this case, the pressure of the generated $\mathrm{H}_{2}$ and $\mathrm{O}_{2}$ influences heterogeneous reactions. The changes of the Gibbs free energy are determined taking into account the effect of the isolated gases pressure [5]:

$$
\Delta G=\Delta G_{0}+R T \ln \left(P_{2} / P_{l}\right),
$$

where $\Delta \mathrm{G}_{0}$ is the Gibbs energy in the standard state, $\mathrm{kJ} / \mathrm{kg}$; R- is the gas constant, $\mathrm{J} /(\mathrm{kg} \mathrm{K})$; $\mathrm{T}$ - is the temperature, $\mathrm{K} ; \mathrm{P}_{2}, \mathrm{P}_{1}$ - the final and initial pressure in the electrolyzer, atm.

The difference between the values of the standard Gibbs energy $(\Delta \mathrm{G})$ and Gibbs energy taking into account the pressure change $\left(\Delta \mathrm{G}_{\mathrm{p}}\right)$ is $\approx 3 \%$, which proves that the pressure increase in the indicated range influences on the electrolysis process insignificantly.

The energy consumption by a membrane compressor (efficiency $60 \%$ ) to compress $1 \mathrm{~m}^{3}$ of $\mathrm{H}_{2}$ and $0,5 \mathrm{~m}^{3}$ of $\mathrm{O}_{2}$ is $475 \mathrm{~W} \cdot \mathrm{h}$. In this case, the total energy consumption for generation and 
compression of these gases amounts, taking into account the compressor equipment consumption, is $\approx 4.2 \mathrm{~kW} \mathrm{~h} / \mathrm{m}^{3}$ (Scheme 3 ).

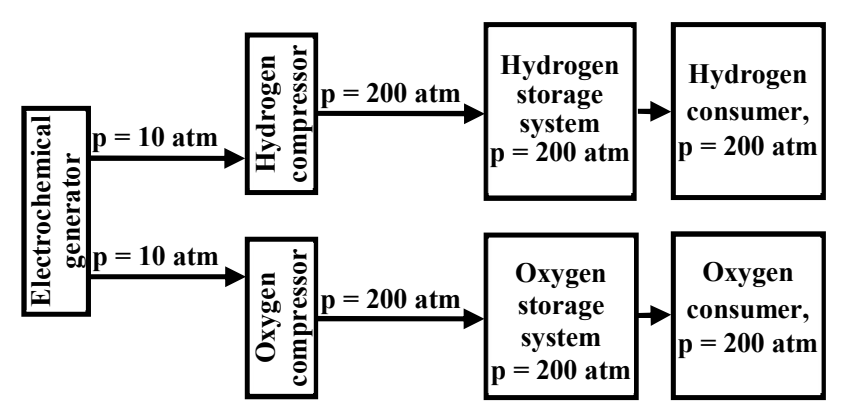

Scheme 3. The technological scheme of $\mathrm{H}_{2}$ and $\mathrm{O}_{2}$ production with additional compressors.

The pressure change in the electrolyzer of $20 \mathrm{~L} / \mathrm{h}$ capacity, when current density is $0,015 \mathrm{~A} / \mathrm{cm}^{2}$, is presented on Figure 2 .

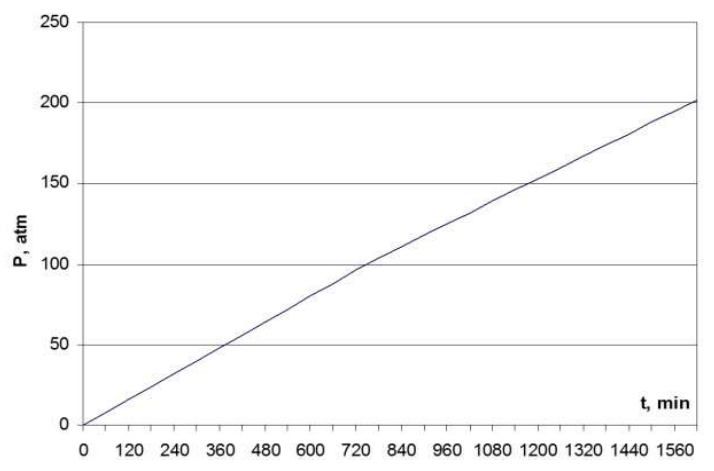

Figure 2. The diagram of pressure increase under $\mathrm{H}_{2}$ and $\mathrm{O}_{2}$ generation by the electrolyzer of 20 liters/hour capacity when current density is $0,015 \mathrm{~A} / \mathrm{cm}^{2}$.

As to the level of technical decisions, simplicity of mounting and servicing, reliability and safety, the electrolyzer implementing the described technology surpasses all of the known analogues (Table 3).
Table 3. The comparative characteristics of the proposed electrolyzer and the industrial analogues.

\begin{tabular}{|c|c|c|c|c|c|c|c|}
\hline $\begin{array}{l}\text { Electrolyzer } \\
\text { title, } \\
\text { manufacturer, } \\
\text { country }\end{array}$ & 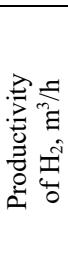 & 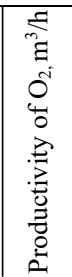 & 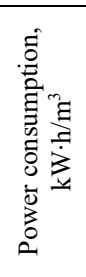 & 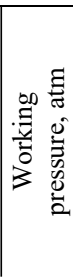 & 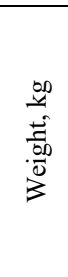 & 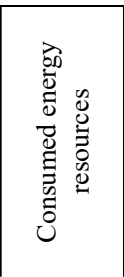 & 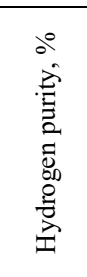 \\
\hline $\begin{array}{l}\text { EHP-1.0-150, } \\
\text { IMEP, Ukraine }\end{array}$ & 1 & 0,5 & $3,9-4,1$ & $1-200$ & 1200 & $\begin{array}{c}\text { Electrical } \\
\text { power, } \\
\mathrm{KOH} \\
\end{array}$ & 99,998 \\
\hline $\begin{array}{c}\text { EU-2/3.2, } \\
\text { "Electrolysis } \\
\text { Technologies" } \\
\text { Ltd., Russia }\end{array}$ & 2 & 1 & 4,7 & 32 & 1300 & $\begin{array}{c}\text { Electrical } \\
\text { power, } \\
\mathrm{KOH}\end{array}$ & 99,8 \\
\hline $\begin{array}{l}\text { BLUE LINE, } \\
\text { «McPhy Energy», } \\
\text { France }\end{array}$ & 1 & 0,5 & 6,2 & $4-8$ & - & $\begin{array}{l}\text { Electrical } \\
\text { power, } \\
\text { water, } \\
\text { nitrogen }\end{array}$ & 99,998 \\
\hline $\begin{array}{l}\text { HOGEN S40, } \\
\text { Proton Onsite, } \\
\text { USA }\end{array}$ & 1,05 & 0,525 & 8,3 & 13,8 & 215 & $\begin{array}{c}\text { Electrical } \\
\text { power, } \\
\text { KOH }\end{array}$ & 99,995 \\
\hline $\begin{array}{c}\text { HySTAT }^{\text {TM}}-\mathrm{A}- \\
\text { 1000Q-40-25, } \\
\text { Hydrogenics } \\
\text { Europe NV, } \\
\text { Belgium }\end{array}$ & 10 & 5 & 4,9 & 25 & 2550 & $\begin{array}{c}\text { Electrical } \\
\text { power, } \\
\mathrm{KOH}\end{array}$ & 99,9 \\
\hline
\end{tabular}

\section{Conclusions:}

1. Separating in time and space the electrolytic processes of water decomposition for gas liberation $\left(\mathrm{H}_{2}\right.$ and $\left.\mathrm{O}_{2}\right)$ provides high pressure (up to $200 \mathrm{~atm}$ and more) and excludes the use of separating membranes in the electrolyzer construction, what results in increase of its reliability and operation safety.

2. Due to increase of voltage in the electrolysis cell, the $\mathrm{OH}$ ions diffusion velocity is decreased as the thickness of the $\left(\mathrm{Fe}(\mathrm{OH})_{2}\right.$, $\left.\mathrm{Fe}(\mathrm{OH})_{3}\right)$ reacted active electrode layer is increased. The difference between the amounts of reacted substance of the porous iron electrode, when the current density is increased from 0.015 to $0.03 \mathrm{~A} / \mathrm{cm}^{2}$, is about $4 \%$. This indicates the 
growth of the reacting layer of the active electrode, $\left(\mathrm{Fe}(\mathrm{OH})_{2}, \mathrm{Fe}(\mathrm{OH})_{3}\right)$, what depends on increase of time of oxidation and reduction hemicycles.

3. The difference between the values of the standard Gibbs energy $(\Delta \mathrm{G})$ and Gibbs energy taking into account the pressure change $\left(\Delta \mathrm{G}_{\mathrm{p}}\right)$ is $\approx$ $3 \%$, what proves that pressure increase in the indicated range (up to $200 \mathrm{~atm}$ ) affects the electrolysis process insignificantly.

4. Under use of the developed electrolysis technology it is required $\approx 3715 \mathrm{~W} \cdot \mathrm{h} / \mathrm{m}^{3}$ of energy to generate $1 \mathrm{~m}^{3}$ of hydrogen $\left(\mathrm{H}_{2}\right)$ and $0.5 \mathrm{~m}^{3}$ of oxygen $\left(\mathrm{O}_{2}\right)$, without taking into account compression of these gases. The compression of gases under electrochemical process consumes $285 \mathrm{~W} \cdot \mathrm{h}$ due to increase of the pressure of generated gases in such membraneless electrolyzer.

5. The described here membrane-less gases generation technology does not require to use mechanical compressors for putting gases into a buffer storage system because in such techology gases are directly generated under high pressure. In the same time, the reliability and safety of electrolyzer operations are increased.

\section{References}

1. Patent of Ukraine 90421 The Electrolysis Device for Generation Highpressure Hydrogen and Oxygen / V.V. Solovey, O.I. Ivanovsky, A.A. Shevchenko, O.S Zhirov, O.O. Makarov (Ukraine). - № 200905223;
Application 25.05.2009; made public on April 26, 2010, Bulletin № 8. -5 p.

2. Patent of Ukraine 98705. Mode of Operation of the Electrolysis Device for Generation High-pressure Hydrogen and Oxygen / V.V. Solovey, A.A. Shevchenko, O.S Zhirov, O.O. Makarov (Ukraine). - № 201013742, Application 19.11.2010; made public on June 11, 2012, Bulletin № 11. - 7 p.

3. Solovey VV, Shevchenko AA, Vorobjova IA, Semikin VM, Koversun SA. Increasing the Efficiency of Hydrogen Generation in the Electrolyzers with a Gas Absorbing Electrode. Herald of Kharkiv National Car-Road University, 2008. - No. 43. - P. $69-72$.

4. Lampart P, Rusanov A, Yershov S, Marcinkowski S, Gardzilewicz A. Validation of a 3D RANS Solver With a State Equation of Thermally Perfect and Calorically Imperfect Gas on a MultiStage Low-Pressure Steam Turbine Flow. Journal of Fluids Engineering 2005;127(1):83.

5. Dickerson R. The Basic Laws of Chemistry: in 2v/ Dickerson R., Gray G., Heit J. - M .: Mir, 1982 - V. 2. -620 p. 